\title{
Quaternary ferrites by batch and continuous flow hydrothermal synthesis: a comparison
}

Received 00th January 20xx, Accepted 00th January 20xx DOI: $10.1039 / x 0 x \times 00000 x$

\begin{abstract}
Michele Bastianello, ${ }^{\mathrm{a}, \mathrm{b}}$ Stefano Diodati, ${ }^{\mathrm{a}, \mathrm{c}}$ Nicola Dengo, ${ }^{\mathrm{a}}$ Liam McCafferty, ${ }^{\mathrm{d}}$ Charles Footer, ${ }^{\mathrm{d}}$ Denis Badocco, ${ }^{\text {a Paolo Pastore, }}{ }^{\text {a Jawwad Darr, }}{ }^{* d}$ and Silvia Gross*a

Crystalline spinel quaternary ferrites $\mathrm{M}_{x} \mathrm{Zn}_{1-\mathrm{x}} \mathrm{Fe}_{2} \mathrm{O}_{4}(\mathrm{M}=\mathrm{Co}, \mathrm{Ni} ; \mathrm{x}=0.2,0.35,0.5,0.65,0.8)$ were synthesised through conventional batch hydrothermal synthesis $(\mathrm{HT})$ at $135^{\circ} \mathrm{C}$ as well as via continuous flow hydrothermal synthesis (CHFS). The as prepared compounds were thoroughly characterised from a compositional (ICP-MS, XPS) and structural (XRD) point of view in order to compare the synthetic approaches and achieve a greater understanding of both how the chosen approach influences the characteristics of the resulting spinel.
\end{abstract}

\section{Introduction}

Spinel ferrites $\mathrm{MFe}_{2} \mathrm{O}_{4}$ are versatile inorganic materials, with numerous functional properties ranging from magnetic, ${ }^{1-3}$ to dielectric, ${ }^{4,5}$ to catalytic ${ }^{6-9}$ and beyond, which allow them to find applications in a wide array of fields. The final properties of the material can strongly depend on numerous factors, including composition, size and shape of crystallite as well as pore size and distribution (in the case of porous ferrites). ${ }^{10-12}$ As a consequence, the exploration of a wide array of ferrites with different synthesis routes and parameters, can allow the discovery of materials with specific characteristics that can be suited to different applications. ${ }^{13-15}$ As a corollary, when exploring these synthetic avenues, it is also important to have a good understanding of how different methodologies and approaches will influence the characteristics of the synthesised materials (and therefore, in turn, their functional properties).

Quaternary spinel ferrites (a subset of spinel ferrites, also known as mixed ferrites, containing two metals ( $M, M^{\prime}$ ) and having chemical formula $\mathrm{M}_{\mathrm{x}} \mathrm{M}^{\prime}{ }_{1-\mathrm{x}} \mathrm{Fe}_{2} \mathrm{O}_{4}$ ) are inorganic crystalline materials of particular interest, because of the presence of two metal species (having different electronic configuration) within the same spinel lattice can give rise to several interesting magnetic, ${ }^{16,17}$ electrical ${ }^{18}$ and catalytic properties. ${ }^{19}$ This allows applications in a broad variety of fields ranging from $\mathrm{CO}_{2}$ decomposition catalysts, ${ }^{19}, 20$ to gas sensing ${ }^{18}$ and several magnetic devices including spin valves, MRAM and spintronics. ${ }^{16}$ Among such ferrites, the zinc spinel ferrite

\footnotetext{
a. Dipartimento di Scienze Chimiche, Università degli Studi di Padova, Via Marzolo 1 - 35131 Padova, Italy.

b. Center for Materials Research (LaMa), Justus-Liebig-Universität Gießen, 35392 Giessen, Germany

c. INSTM, UdR Padova, Via Marzolo 1 - 35131 Padova, Italy.

d. Department of Chemistry, University College London, Gower Street, London, WC1H OAJ, UK.

Electronic Supplementary Information (ESI) available: survey XPS spectra the $\mathrm{Co}_{x} \mathrm{Zn}_{1}$ ${ }_{x} \mathrm{Fe}_{2} \mathrm{O}_{4}$ samples; surface composition (atomic \%) of the samples obtained through XPS. See DOI: $10.1039 / x 0 x x 00000 x$
}

$\mathrm{ZnFe}_{2} \mathrm{O}_{4}$ is a well-known compound with a normal spinel structure ${ }^{21}$ (that is to say, $\mathrm{Zn}^{11}$ occupies tetrahedral A sites within the spinel matrix, whereas Fe ${ }^{\text {III }}$ occupies octahedral B sites). ${ }^{22}$ By partially substituting $\mathrm{Zn}$ with other metals that have the tendency to yield inverse (such as $\mathrm{Co})^{23}$ or partially inverse spinels (such as $\mathrm{Ni}$ ), ${ }^{24}$ changes are generated in its crystal structure allowing the tuning of the electronic and magnetic properties of the materials. This allows the preparation of materials with extremely useful functional properties, especially in the field of magnetic devices ${ }^{25,} 26$ due to its well documented magnetic and dielectric properties. ${ }^{27-31}$

Most approaches aiming to prepare mixed ferrites involve combustion reactions ${ }^{17}, 28,32$ or coprecipitation followed by a heat-treatment step at higher temperatures. ${ }^{16,}$ 18, 19, 25 Other approaches ${ }^{17}$ such as solid-state reactions, ${ }^{25}$ micro-emulsion, ${ }^{33}$ batch hydrothermal, ${ }^{19}$ reverse micelle $^{34}$ and evaporation routes. ${ }^{35,} 36$

This paper we explore for the first time the synthesis of crystalline quaternary ferrites $\mathrm{Co}_{x} \mathrm{Zn}_{1-\mathrm{x}} \mathrm{Fe}_{2} \mathrm{O}_{4}$ and $\mathrm{Ni}_{x} \mathrm{Zn}_{1-\mathrm{x}} \mathrm{Fe}_{2} \mathrm{O}_{4}$ $(X=0,0.2,0.35,0.5,0.65,0.8,1)$ through a low-temperature conventional batch hydrothermal $(\mathrm{HT})$ synthesis as well as through continuous hydrothermal flow synthesis (CHFS) under supercritical conditions. The former approach was adapted from a protocol previously used for the synthesis of binary ferrites ${ }^{37,38}$ by adding a further metal salt. The CHFS method is an extremely versatile synthesis approach that required minimal adaption from pre-existing protocols ${ }^{39}$ with all metal salt solutions pumped through a single feed. Continuous flow hydrothermal synthesis (CHFS) is a scalable route for the rapid synthesis of nano-materials, applicable to a diverse range of applications. Metal salts are intimately mixed with supercritical water $\left(\mathrm{T}>374^{\circ} \mathrm{C}, \mathrm{P}>22 \mathrm{MPa}\right.$ ) in a patented confined jet mixer, inducing instantaneous mixing of the two fluids, such that the solubility of the metal source decreases, and the nucleation of nanoparticles (titanates, ferrites, sulphides etc) ensues. Reaction times are typically $<5 \mathrm{~s}$, additionally both nucleation and growth processes can be controlled and 


\section{ARTICLE}

Tab. 1. Solution volumes employed per target compound during batch hydrothermal (HT) synthesis.

\begin{tabular}{|c|c|c|c|c|}
\hline Sample name & Compound & V sol A (mL) & V sol B (mL) & V sol C $(\mathrm{mL})$ \\
\hline HT01 & $\mathrm{Co}_{0.2} \mathrm{Zn}_{0.8} \mathrm{Fe}_{2} \mathrm{O}_{4}$ & 0 & 2 & 8 \\
\hline HT02 & $\mathrm{Co}_{0.35} \mathrm{Zn}_{0.65} \mathrm{Fe}_{2} \mathrm{O}_{4}$ & 0 & 3.5 & 6.5 \\
\hline HT03 & $\mathrm{Co}_{0.5} \mathrm{Zn}_{0.5} \mathrm{Fe}_{2} \mathrm{O}_{4}$ & 0 & 5 & 5 \\
\hline HT04 & $\mathrm{Co}_{0.65} \mathrm{Zn}_{0.35} \mathrm{Fe}_{2} \mathrm{O}_{4}$ & 0 & 6.5 & 3.5 \\
\hline HT05 & $\mathrm{Co}_{0.8} \mathrm{Zn}_{0.2} \mathrm{Fe}_{2} \mathrm{O}_{4}$ & 0 & 8 & 2 \\
\hline HT06 & $\mathrm{Ni}_{0.2} \mathrm{Zn}_{0.8} \mathrm{Fe}_{2} \mathrm{O}_{4}$ & 8 & 2 & 0 \\
\hline HT07 & $\mathrm{Ni}_{0.35} \mathrm{Zn}_{0.65} \mathrm{Fe}_{2} \mathrm{O}_{4}$ & 6.5 & 3.5 & 0 \\
\hline HT08 & $\mathrm{Ni}_{0.5} \mathrm{Zn}_{0.5} \mathrm{Fe}_{2} \mathrm{O}_{4}$ & 5 & 5 & 0 \\
\hline HT09 & $\mathrm{Ni}_{0.65} \mathrm{Zn}_{0.35} \mathrm{Fe}_{2} \mathrm{O}_{4}$ & 3.5 & 6.5 & 0 \\
\hline HT10 & $\mathrm{Ni}_{0.8} \mathrm{Zn}_{0.2} \mathrm{Fe}_{2} \mathrm{O}_{4}$ & 2 & 8 & 0 \\
\hline HTZn & $\mathrm{ZnFe}_{2} \mathrm{O}_{4}$ & 10 & 0 & 0 \\
\hline $\mathrm{HTNi}$ & $\mathrm{NiFe}_{2} \mathrm{O}_{4}$ & 0 & 10 & 0 \\
\hline HTCo & $\mathrm{CoFe}_{2} \mathrm{O}_{4}$ & 0 & 0 & 10 \\
\hline
\end{tabular}

Tab. 2. Solution concentrations employed per target compound during continuous flow (CHFS) synthesis. $\mathrm{A} 0.1 \mathrm{~mol} \cdot \mathrm{dm}^{-3} \mathrm{concentration}$ of Fe( $\left(\mathrm{NO}_{3}\right)_{3}$ was utilised in the metal feed of all samples.

\begin{tabular}{|c|c|c|c|c|}
\hline Sample Name & Compound & $\mathrm{M} \mathrm{Zn}\left(\mathrm{NO}_{3}\right)_{2}\left(\mathrm{Mol} \cdot \mathrm{dm}^{-3}\right)$ & $\begin{array}{c}\mathrm{M} \mathrm{Co}\left(\mathrm{NO}_{3}\right)_{2} \\
\left(\mathrm{Mol} \cdot \mathrm{dm}^{-3}\right)\end{array}$ & $\begin{array}{l}\mathrm{M} \mathrm{Ni}\left(\mathrm{NO}_{3}\right)_{2} \\
\left(\mathrm{Mol} \cdot \mathrm{dm}^{-3}\right) \\
\end{array}$ \\
\hline CFZn & $\mathrm{ZnFe}_{2} \mathrm{O}_{4}$ & 0.05 & - & - \\
\hline CF01 & $\left(\mathrm{Co}_{0.2} \mathrm{Zn}_{0.8}\right) \mathrm{Fe}_{2} \mathrm{O}_{4}$ & 0.04 & 0.01 & - \\
\hline CF02 & $\left(\mathrm{Co}_{0.35} \mathrm{Zn}_{0.65}\right) \mathrm{Fe}_{2} \mathrm{O}_{4}$ & 0.0325 & 0.0175 & - \\
\hline CF03 & $\left(\mathrm{Co}_{0.5} \mathrm{Zn}_{0.5}\right) \mathrm{Fe}_{2} \mathrm{O}_{4}$ & 0.025 & 0.025 & - \\
\hline CF04 & $\left(\mathrm{Co}_{0.65} \mathrm{Zn}_{0.35}\right) \mathrm{Fe}_{2} \mathrm{O}_{4}$ & 0.0175 & 0.0325 & - \\
\hline CFCo & $\mathrm{CoFe}_{2} \mathrm{O}_{4}$ & - & 0.05 & - \\
\hline CF06 & $\left(\mathrm{Ni}_{0.2} \mathrm{Zn}_{0.8}\right) \mathrm{Fe}_{2} \mathrm{O}_{4}$ & 0.04 & - & 0.01 \\
\hline CF07 & $\left(\mathrm{Ni}_{0.35} \mathrm{Zn}_{0.65}\right) \mathrm{Fe}_{2} \mathrm{O}_{4}$ & 0.0325 & - & 0.0175 \\
\hline CF08 & $\left(\mathrm{Ni}_{0.5} \mathrm{Zn}_{0.5}\right) \mathrm{Fe}_{2} \mathrm{O}_{4}$ & 0.025 & - & 0.025 \\
\hline CF09 & $\left(\mathrm{Ni}_{0.65} \mathrm{Zn}_{0.35}\right) \mathrm{Fe}_{2} \mathrm{O}_{4}$ & 0.0175 & - & 0.0325 \\
\hline CF10 & $\left(\mathrm{Ni}_{0.8} \mathrm{Zn}_{0.2}\right) \mathrm{Fe}_{2} \mathrm{O}_{4}$ & 0.01 & - & 0.04 \\
\hline
\end{tabular}

manipulated by varying process parameters, which yields various benefits over conventional batch hydrothermal syntheses. The materials resulting from the two synthetic approaches were thoroughly characterised from a structural (XRD) and compositional (XPS, ICP-MS) point of view and the results were evaluated in order to achieve a good comparison between batch hydrothermal and CHFS hydrothermal approaches.

\section{Experimental section}

Synthesis of $\mathrm{M}_{\mathrm{x}} \mathrm{Zn}_{1-\mathrm{x}} \mathrm{Fe}_{2} \mathrm{O}_{4}$ ferrites ( $\mathrm{M}=\mathrm{Ni}, \mathrm{Co}$ ) via lowtemperature HT synthesis
Reagents were purchased from the following suppliers and used as-purchased: potassium hydroxide, Fe lll nitrate nonahydrate, cobalt nitrate hexahydrate, nickel nitrate hexahydrate and zinc nitrate hexahydrate were purchased from Sigma Aldrich (Milan, Italy).

\section{HT synthesis of nanoparticles}

For the synthesis of the spinel ferrites through batch HT synthesis, three solutions were prepared: solution A [104.46 $\left.\mathrm{mM} \mathrm{Fe}\left(\mathrm{NO}_{3}\right)_{3} \cdot\left(\mathrm{H}_{2} \mathrm{O}\right)_{9}, 52.23 \mathrm{mM} \mathrm{Zn}\left(\mathrm{NO}_{3}\right)_{3} \cdot\left(\mathrm{H}_{2} \mathrm{O}\right)_{6}\right]$, solution $B$ [104.46 mM Fe( $\left.\left(\mathrm{NO}_{3}\right)_{3} \cdot\left(\mathrm{H}_{2} \mathrm{O}\right)_{9}, 52.23 \mathrm{mM} \mathrm{Ni}\left(\mathrm{NO}_{3}\right)_{3} \cdot\left(\mathrm{H}_{2} \mathrm{O}\right)_{6}\right]$ and solution $\mathrm{C} \quad\left[104.46 \mathrm{mM} \quad \mathrm{Fe}\left(\mathrm{NO}_{3}\right)_{3} \cdot\left(\mathrm{H}_{2} \mathrm{O}\right)_{9}, \quad 52.23 \mathrm{mM}\right.$ $\left.\mathrm{Co}\left(\mathrm{NO}_{3}\right)_{3} \cdot\left(\mathrm{H}_{2} \mathrm{O}\right)_{6}\right]$. Different volumes of each solution were places in a $23 \mathrm{ml}$ PTFE liner (A255AC Parr Instrument Company) 
according to the stoichiometry of the desired final compound (Table 1), under stirring.

To each liner, $1 \mathrm{~mL}$ of $10 \mathrm{M} \mathrm{KOH}$ solution was added under vigorous stirring. After two further minutes vigorous stirring, the liners were sealed and placed in mod. 4745 General Purpose Acid-Digestion Bombs (Parr Instrument Company Parr Instrument Company). The bombs were placed in an oven at $135{ }^{\circ} \mathrm{C}$ for 24 hours. The resulting powders were isolated through centrifugation at $10 \mathrm{kRPM}$, washed with deionised water and dried in an open-air oven at $75^{\circ} \mathrm{C}$.

\section{Synthesis of $\mathrm{M}_{\mathrm{x}} \mathrm{Zn}_{1-\mathrm{x}} \mathrm{Fe}_{2} \mathrm{O}_{4}$ ferrites ( $\mathrm{M}=\mathrm{Ni}, \mathrm{Co}$ ) via CHFS}

Reagents were purchased from the following suppliers and used as-purchased: zinc nitrate hexahydrate, 98\% (Sigma Aldrich, Dorset, UK), iron nitrate nonahydrate, 99+\% (Sigma Aldrich, Dorset, UK), nickel nitrate hydrate, 99.99\% (Alfa Aesar, Lancashire, UK), cobalt nitrate hydrate, 99.99\% (Alfa Aesar, Lancashire, UK), hydrogen peroxide, 30\% w/w (Honeywell, Seelze, Germany) and potassium hydroxide (Fisher Scientific, Leicestershire, UK).

\section{High-throughput CHFS of nanoparticles}

A schematic diagram of the reactor setup is shown in Figure 1. Two pumps (Primeroyal K, Milton Roy, Pont Saint-Pierre, France) were used to provide the supercritical water (containing $0.5 \mathrm{M} \mathrm{H}_{2} \mathrm{O}_{2}$ ) and base (1.0 M KOH) feeds at 80 and $40 \mathrm{~mL} \mathrm{~min}^{-1}$, respectively (pumps $\mathrm{P} 1$ and $\mathrm{P} 3$ ). $10 \mathrm{M} \Omega / \mathrm{cm}$ deionised water, purified using a Millipore $\mathrm{Elix}^{\circledR}$ Essential water purification system was fed from pump P1 and heated to $450{ }^{\circ} \mathrm{C}$ in flow using a $7 \mathrm{~kW}$ custom-built electrical water heater. The metal precursor feed was pumped by $\mathrm{P} 2$, delivering a total flow rate $40 \mathrm{~mL} \mathrm{~min}-1$. The premixed precursor solutions consisted of the desired ratios of each metal nitrate precursor, with a total metal salt concentration of $0.15 \mathrm{M}$ (Table 2). The metal precursor feed delivered from pump P2 was first mixed with the $1.0 \mathrm{M} \mathrm{KOH}$ base feed in flow (from pump P3), before the combined mixture was introduced to a stream of supercritical water (from pump P1) in a patented Confined Jet Mixer (CJM). ${ }^{40}$ The reaction of the precursor solutions in the CJM, resulted in the rapid crystallization of nanoparticles, with a theoretical mixing temperature of $335{ }^{\circ} \mathrm{C}$, based on the flow rates and temperatures used. The particle-containing aqueous flow was cooled to ca. $40{ }^{\circ} \mathrm{C}$ using a $1.5 \mathrm{~m}$ pipe-in-pipe heat exchange column, before passing through a back-pressure regulator (BPR). The resultant nanoparticle slurries were collected in beakers and were then cleaned by repeated centrifugation and washing with deionised water until the supernatant had conductivity below $50 \mu \mathrm{S} / \mathrm{cm}$ as measured using a conductivity probe (model HI98311, Hanna Instruments, Leighton Buzzard, UK). The concentrated, cleaned slurry was then freeze-dried by slowly heating from $-60^{\circ} \mathrm{C}$ to $25^{\circ} \mathrm{C}$, under a vacuum of $<13 \mathrm{~Pa}$, over $24 \mathrm{~h}$ using a Virtis Genesis 35XL freeze-drier.

\section{Sample characterisation}

\section{X-ray photoelectron spectroscopy (XPS)}

Samples were investigated by XPS measurements with a $\Phi$ 5600ci Perkin-Elmer spectrometer, using a standard magnesium
( $\mathrm{Mg} \mathrm{K}_{\alpha}$ ) source with an energy of $1253.6 \mathrm{eV}$ operating at $220 \mathrm{~W}$. The choice to employ a standard Mg source (as opposed to the more common Al $\mathrm{K}_{\alpha}$ source) was made to avoid the overlap of Co2p and $\mathrm{FeL}_{3} \mathrm{M}_{45} \mathrm{M}_{45}$ peaks (both sets falling in the 775-795 eV interval with an $\mathrm{Al}$ source) and of the $\mathrm{Fe} 2 \mathrm{p}$ and $\mathrm{CoL}_{2} \mathrm{M}_{23} \mathrm{M}_{45}$ (1P) peaks (all belonging to the $710-720 \mathrm{eV}$ region). ${ }^{41}$

The X-ray source employed was located at $54.7^{\circ}$ relative to the analyser axis. The working pressure was $<5 \cdot 10^{-8} \mathrm{~Pa} \sim 10-11$ torr. The calibration was based on the binding energy (B.E.) of the $A u 4 f_{7 / 2}$ line at $83.9 \mathrm{eV}$ with respect to the Fermi level. The standard deviation for the B.E. values was $0.15 \mathrm{eV}$. The reported B.E. were corrected for the B.E. charging effects, assigning the B.E. value of $284.6 \mathrm{eV}$ to the $\mathrm{C} 1 \mathrm{~s}$ line of carbon. ${ }^{41,42}$ Survey scans were obtained in the $0-1200 \mathrm{eV}$ range (pass energy $58.7 \mathrm{eV}, 0.5$ eV/step, $25 \mathrm{~ms} / \mathrm{step})$. Detailed scans (11.75-29.35 eV pass energy, $0.1 \mathrm{eV} / \mathrm{step}, 50-150 \mathrm{~ms} / \mathrm{step})$ were recorded for relevant regions (O1s, C1s, Fe2p, Co2p, Zn2p). The atomic composition, after a Shirley-type background subtraction, ${ }^{43}$ was evaluated using the Mulipak Program using sensitivity factors provided by Perkin Elmer. Assignment of the peaks was carried out according to literature data.

Inductively coupled plasma - mass spectrometry (ICP-MS)

ICP-MS analysis was carried out with an Agilent Technologies 7700x ICP-MS (Agilent Technologies International Japan, Ltd., Tokyo, Japan). The instrument was equipped with an octupole collision cell operating in kinetic energy discrimination mode (used for the removal of polyatomic interferences and argonbased interferences). Optimal performance was attained by using the collision cell in He mode. Operating conditions and data acquisition parameters were chosen according to a previous work. ${ }^{44}$ The instrument was tuned daily using a tuning solution containing $1 \mu \mathrm{g} / \mathrm{L}{ }^{140} \mathrm{Ce},{ }^{7} \mathrm{Li},{ }^{205} \mathrm{Tl}$, and ${ }^{89} \mathrm{Y}$ (Agilent Technologies, UK). A $100 \mu \mathrm{g} / \mathrm{L}$ solution (Aristar, BDH, UK) containing ${ }^{115} \mathrm{In}$, prepared in $3.5 \% \mathrm{HNO}_{3}(\mathrm{w} / \mathrm{w})$ was used as internal standard through addition to the sample solution via a T-junction.

All solutions were prepared in MilliQ ultrapure water obtained using a Millipore Plus System (Milan, Italy, resistivity 18.2 MOhm cm-1). Multielement standard solutions for calibration

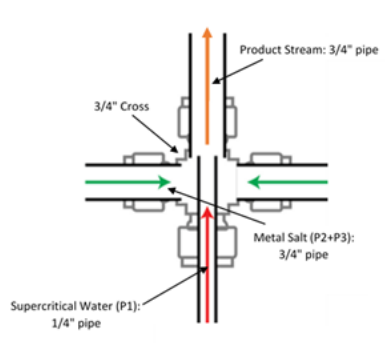

a)

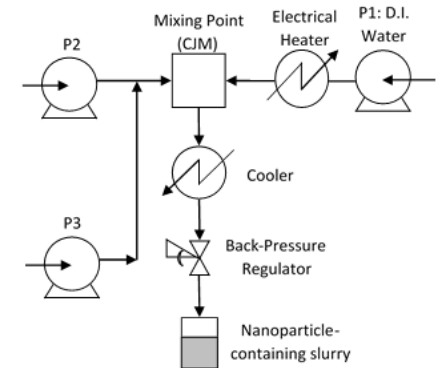

b)
Fig. 1 a) Diagram representing the confined jet mixer CJM. b) Schematic of the CHFS process, which demonstrates how the heated water from $\mathrm{P} 1$ is combined with the aqueous precursors from $\mathrm{P} 2$ and $\mathrm{P} 3$ at the $\mathrm{CJM}$ mixing point 


\section{ARTICLE}

Tab. 3. ICP-MS results with recovery values based on expected weight abundance.

\begin{tabular}{|c|c|c|c|c|c|c|}
\hline Sample & Compound & Co \%rec & $\mathrm{Ni} \%$ rec & Zn \%rec & Fe \%rec & Calculated formula \\
\hline НT01 & $\mathrm{Co}_{0.2} \mathrm{Zn}_{0.8} \mathrm{Fe}_{2} \mathrm{O}_{4}$ & 98 & - & 100 & 101 & $\mathrm{Co}_{0.19} \mathrm{Zn}_{0.79} \mathrm{Fe}_{2} \mathrm{O}_{4}$ \\
\hline HT02 & $\mathrm{Co}_{0.35} \mathrm{Zn}_{0.65} \mathrm{Fe}_{2} \mathrm{O}_{4}$ & 98 & - & 95 & 97 & $\mathrm{Co}_{0.35} \mathrm{Zn}_{0.64} \mathrm{Fe}_{2} \mathrm{O}_{4}$ \\
\hline HT03 & $\mathrm{Co}_{0.5} \mathrm{Zn}_{0.5} \mathrm{Fe}_{2} \mathrm{O}_{4}$ & 94 & - & 96 & 97 & $\mathrm{Co}_{0.48} \mathrm{Zn}_{0.49} \mathrm{Fe}_{2} \mathrm{O}_{4}$ \\
\hline HT04 & $\mathrm{Co}_{0.65} \mathrm{Zn}_{0.35} \mathrm{Fe}_{2} \mathrm{O}_{4}$ & 94 & - & 96 & 96 & $\mathrm{Co}_{0.64} \mathrm{Zn}_{0.35} \mathrm{Fe}_{2} \mathrm{O}_{4}$ \\
\hline HT05 & $\mathrm{Co}_{0.8} \mathrm{Zn}_{0.2} \mathrm{Fe}_{2} \mathrm{O}_{4}$ & 98 & - & 102 & 100 & $\mathrm{Co}_{0.78} \mathrm{Zn}_{0.20} \mathrm{Fe}_{2} \mathrm{O}_{4}$ \\
\hline HT06 & $\mathrm{Ni}_{0.2} \mathrm{Zn}_{0.8} \mathrm{Fe}_{2} \mathrm{O}_{4}$ & - & 96 & 97 & 97 & $\mathrm{Ni}_{0.20} \mathrm{Zn}_{0.80} \mathrm{Fe}_{2} \mathrm{O}_{4}$ \\
\hline HT07 & $\mathrm{Ni}_{0.35} \mathrm{Zn}_{0.65} \mathrm{Fe}_{2} \mathrm{O}_{4}$ & - & 89 & 89 & 90 & $\mathrm{Ni}_{0.35} \mathrm{Zn}_{0.64} \mathrm{Fe}_{2} \mathrm{O}_{4}$ \\
\hline HT08 & $\mathrm{Ni}_{0.5} \mathrm{Zn}_{0.5} \mathrm{Fe}_{2} \mathrm{O}_{4}$ & - & 97 & 99 & 98 & $\mathrm{Ni}_{0.49} \mathrm{Zn}_{0.51} \mathrm{Fe}_{2} \mathrm{O}_{4}$ \\
\hline HT09 & $\mathrm{Ni}_{0.65} \mathrm{Zn}_{0.35} \mathrm{Fe}_{2} \mathrm{O}_{4}$ & - & 96 & 98 & 97 & $\mathrm{Ni}_{0.64} \mathrm{Zn}_{0.35} \mathrm{Fe}_{2} \mathrm{O}_{4}$ \\
\hline HT10 & $\mathrm{Ni}_{0.8} \mathrm{Zn}_{0.2} \mathrm{Fe}_{2} \mathrm{O}_{4}$ & - & 98 & 101 & 98 & $\mathrm{Ni}_{0.80} \mathrm{Zn}_{0.21} \mathrm{Fe}_{2} \mathrm{O}_{4}$ \\
\hline CF01 & $\mathrm{Co}_{0.2} \mathrm{Zn}_{0.8} \mathrm{Fe}_{2} \mathrm{O}_{4}$ & 102 & - & 92 & 99 & $\mathrm{Co}_{0.21} \mathrm{Zn}_{0.74} \mathrm{Fe}_{2} \mathrm{O}_{4}$ \\
\hline CF02 & $\mathrm{Co}_{0.35} \mathrm{Zn}_{0.65} \mathrm{Fe}_{2} \mathrm{O}_{4}$ & 102 & - & 95 & 96 & $\mathrm{Co}_{0.37} \mathrm{Zn}_{0.64} \mathrm{Fe}_{2} \mathrm{O}_{4}$ \\
\hline CF03 & $\mathrm{Co}_{0.5} \mathrm{Zn}_{0.5} \mathrm{Fe}_{2} \mathrm{O}_{4}$ & 101 & - & 97 & 100 & $\mathrm{Co}_{0.51} \mathrm{Zn}_{0.49} \mathrm{Fe}_{2} \mathrm{O}_{4}$ \\
\hline CF04 & $\mathrm{Co}_{0.65} \mathrm{Zn}_{0.35} \mathrm{Fe}_{2} \mathrm{O}_{4}$ & 92 & - & 81 & 86 & $\mathrm{Co}_{0.70} \mathrm{Zn}_{0.33} \mathrm{Fe}_{2} \mathrm{O}_{4}$ \\
\hline CF05 & $\mathrm{Co}_{0.8} \mathrm{Zn}_{0.2} \mathrm{Fe}_{2} \mathrm{O}_{4}$ & 92 & - & 87 & 84 & $\mathrm{Co}_{0.88} \mathrm{Zn}_{0.21} \mathrm{Fe}_{2} \mathrm{O}_{4}$ \\
\hline CF07 & $\mathrm{Ni}_{0.35} \mathrm{Zn}_{0.65} \mathrm{Fe}_{2} \mathrm{O}_{4}$ & - & 104 & 100 & 104 & $\mathrm{Ni}_{0.35} \mathrm{Zn}_{0.63} \mathrm{Fe}_{2} \mathrm{O}_{4}$ \\
\hline CF08 & $\mathrm{Ni}_{0.5} \mathrm{Zn}_{0.5} \mathrm{Fe}_{2} \mathrm{O}_{4}$ & - & 70 & 66 & 70 & $\mathrm{Ni}_{0.50} \mathrm{Zn}_{0.47} \mathrm{Fe}_{2} \mathrm{O}_{4}$ \\
\hline CF09 & $\mathrm{Ni}_{0.65} \mathrm{Zn}_{0.35} \mathrm{Fe}_{2} \mathrm{O}_{4}$ & - & 101 & 96 & 102 & $\mathrm{Ni}_{0.64} \mathrm{Zn}_{0.33} \mathrm{Fe}_{2} \mathrm{O}_{4}$ \\
\hline CF10 & $\mathrm{Ni}_{0.8} \mathrm{Zn}_{0.2} \mathrm{Fe}_{2} \mathrm{O}_{4}$ & - & 91 & 89 & 91 & $\mathrm{Ni}_{0.80} \mathrm{Zn}_{0.20} \mathrm{Fe}_{2} \mathrm{O}_{4}$ \\
\hline
\end{tabular}

aError could not be calculated for this sample, as only one suitable reflection was available

were prepared in $3.5 \%$ nitric acid $(w / w)$ by gravimetric serial dilution at twelve different concentrations (min. $1 \mathrm{ng} \mathrm{L}^{-1}-$ max. $100 \mathrm{mg} \mathrm{L}^{-1}$ ). All regressions were linear with a determination coefficient $\left(R^{2}\right)$ larger than 0.9999 .

The internal standard mixture (Agilent, 5183-4681) containing $\mathrm{Bi}, \mathrm{Ge}, \mathrm{In}, \mathrm{Sc}, \mathrm{Tb}, \mathrm{Y}$ and $\mathrm{Li}(6)$ at $10 \mu \mathrm{g} / \mathrm{mL}$ each in $5 \% \mathrm{HNO}_{3}$ was used. The internal standard was added to the sample solution via a T-junction.

Multielement standard solutions for calibration were prepared by gravimetric serial dilution at five different concentrations (from $200 \mu \mathrm{g} / \mathrm{L}$ to $1000 \mu \mathrm{g} / \mathrm{L}$ ). The solvent used was $\mathrm{HNO}_{3} 69 \%$ diluted to $5 \%$ with MilliQ water. The parameters of the calibration lines were obtained by using the Theil-Sen nonparametric regression technique. ${ }^{45}$

Samples were digested as follows: a suitable amount of sample (25 mg) was accurately weighed and digested with $3 \mathrm{~g} \mathrm{HNO}_{3} 69 \%$ wt. at $100{ }^{\circ} \mathrm{C}$ for $2 \mathrm{~h}$. The resulting solution was diluted with the same solvent used for calibrations. The digestion procedure was repeated 2 times. Each digested solution was diluted to 2 concentration levels and each solution was measured 3 times with the ICP-MS setup.

\section{X-ray Diffraction (XRD)}

Samples were investigated by XRD using a Bragg-Brentano geometry Panalytical Empyrean diffractometer, having an angular accuracy of $0.001^{\circ}$ and angular resolution better than
0.01 employing the $\mathrm{CuK}_{\alpha}$ radiation was used. The $\mathrm{X}$-ray patterns were collected with a $\lambda$ of $1.5406 \AA$, a $0.013^{\circ}(2 \theta)$ scan step and 200 seconds per step acquisition time in the $10-80^{\circ}$ range. The profiles were fitted using GSAS-II software. ${ }^{46}$ A Chebyschev function ${ }^{47}$ with ten coefficients was used to fit the pattern baseline, the parameters fitted where the sample displacement and the unit cell parameter.

\section{Results and discussion}

\section{Composition}

Synthesised ferrites were firstly analysed compositionally in order to gain accurate information on the stoichiometry of the produced materials and, in particular, on how well the synthesis protocols afforded materials with the intended $\mathrm{M} / \mathrm{Zn}$ ratio. Given its ability to detect metal traces down to the $\mathrm{ppb}$ range, the ICP-MS technique was chosen as the ideal method for this purpose.

Results in Table 3 are expressed in terms of recovery, that is to say the \% amount of a given metal that was detected by the instrument compared to the expected value (based on the expected stoichiometry and the mass of the analysed sample). As can be seen from the above table, most samples showed excellent agreement with the expected values and high 
Tab. 4. Crystallite sizes of the synthesised samples calculated using Scherrer's equation on different reflections.

\begin{tabular}{|c|c|c|c|c|c|}
\hline \multicolumn{6}{|c|}{ Crystallite size } \\
\hline \multicolumn{3}{|c|}{ CHFS } & \multicolumn{3}{|c|}{ Batch } \\
\hline Sample & Compound & Avg. Size $(\mathrm{nm})$ & Sample & Compound & Avg. Size $(\mathrm{nm})$ \\
\hline CF01 & $\mathrm{Co}_{0.2} \mathrm{Zn}_{0.8} \mathrm{Fe}_{2} \mathrm{O}_{4}$ & $8.2 \pm 1.0$ & HT01 & $\mathrm{Co}_{0.2} \mathrm{Zn}_{0.8} \mathrm{Fe}_{2} \mathrm{O}_{4}$ & $7.9 \pm 1.3$ \\
\hline CF02 & $\mathrm{Co}_{0.35} \mathrm{Zn}_{0.65} \mathrm{Fe}_{2} \mathrm{O}_{4}$ & $7.7 \pm 1.4$ & HTO2 & $\mathrm{Co}_{0.35} \mathrm{Zn}_{0.65} \mathrm{Fe}_{2} \mathrm{O}_{4}$ & $7.9 \pm 0.5$ \\
\hline CF03 & $\mathrm{Co}_{0.5} \mathrm{Zn}_{0.5} \mathrm{Fe}_{2} \mathrm{O}_{4}$ & $6.3 \pm 0.7$ & HT03 & $\mathrm{Co}_{0.5} \mathrm{Zn}_{0.5} \mathrm{Fe}_{2} \mathrm{O}_{4}$ & $7.6 \pm 1.9$ \\
\hline CF04 & $\mathrm{Co}_{0.65} \mathrm{Zn}_{0.35} \mathrm{Fe}_{2} \mathrm{O}_{4}$ & $5.8 \pm 0.8$ & HTO4 & $\mathrm{Co}_{0.65} \mathrm{Zn}_{0.35} \mathrm{Fe}_{2} \mathrm{O}_{4}$ & $6.4 \pm 0.5$ \\
\hline CF05 & $\mathrm{Co}_{0.8} \mathrm{Zn}_{0.2} \mathrm{Fe}_{2} \mathrm{O}_{4}$ & $5.6 \pm 0.5$ & HT05 & $\mathrm{Co}_{0.8} \mathrm{Zn}_{0.2} \mathrm{Fe}_{2} \mathrm{O}_{4}$ & $9.8 \pm 1.0$ \\
\hline CF06 & $\mathrm{Ni}_{0.2} \mathrm{Zn}_{0.8} \mathrm{Fe}_{2} \mathrm{O}_{4}$ & $9.6 \pm 0.8$ & HT06 & $\mathrm{Ni}_{0.2} \mathrm{Zn}_{0.8} \mathrm{Fe}_{2} \mathrm{O}_{4}$ & $6.5 \pm 0.35$ \\
\hline CF07 & $\mathrm{Ni}_{0.35} \mathrm{Zn}_{0.65} \mathrm{Fe}_{2} \mathrm{O}_{4}$ & $10.8 \pm 0.9$ & HT07 & $\mathrm{Ni}_{0.35} \mathrm{Zn}_{0.65} \mathrm{Fe}_{2} \mathrm{O}_{4}$ & $9.0 \pm 2.0$ \\
\hline CF08 & $\mathrm{Ni}_{0.5} \mathrm{Zn}_{0.5} \mathrm{Fe}_{2} \mathrm{O}_{4}$ & $11.0 \pm 0.8$ & HT08 & $\mathrm{Ni}_{0.5} \mathrm{Zn}_{0.5} \mathrm{Fe}_{2} \mathrm{O}_{4}$ & $11.2 \pm 0.4$ \\
\hline CF09 & $\mathrm{Ni}_{0.65} \mathrm{Zn}_{0.35} \mathrm{Fe}_{2} \mathrm{O}_{4}$ & $11.0 \pm 0.8$ & HT09 & $\mathrm{Ni}_{0.65} \mathrm{Zn}_{0.35} \mathrm{Fe}_{2} \mathrm{O}_{4}$ & $13.7 \pm 1.9$ \\
\hline CF10 & $\mathrm{Ni}_{0.8} \mathrm{Zn}_{0.2} \mathrm{Fe}_{2} \mathrm{O}_{4}$ & $7.8 \pm 1.4$ & HT10 & $\mathrm{Ni}_{0.8} \mathrm{Zn}_{0.2} \mathrm{Fe}_{2} \mathrm{O}_{4}$ & $14.8 \pm 1.9$ \\
\hline $\mathrm{CFNi}$ & $\mathrm{NiFe}_{2} \mathrm{O}_{4}$ & $4.8 \pm 0.7$ & $\mathrm{HTNi}$ & $\mathrm{NiFe}_{2} \mathrm{O}_{4}$ & $31.7 \pm 3.3$ \\
\hline CFZn & $\mathrm{ZnFe}_{2} \mathrm{O}_{4}$ & $9.8 \pm 1.1$ & HTZn & $\mathrm{ZnFe}_{2} \mathrm{O}_{4}$ & $10.7 \pm 2.3$ \\
\hline CFCo & $\mathrm{CoFe}_{2} \mathrm{O}_{4}$ & $4.5^{\text {(a) }}$ & HTCo & $\mathrm{CoFe}_{2} \mathrm{O}_{4}$ & $5.7 \pm 0.2$ \\
\hline
\end{tabular}

${ }^{a}$ Error could not be calculated for this sample, as only one suitable reflection was available
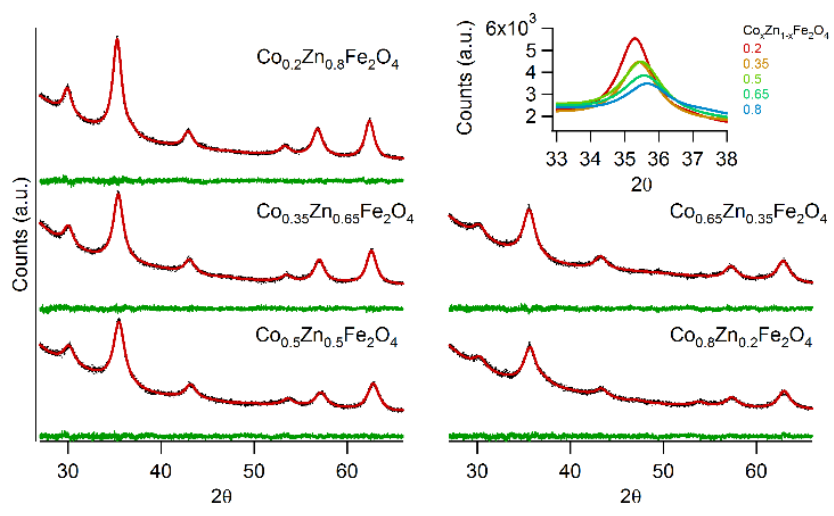

Fig. 2 Refined XRD patterns with fitting residuals (green) of the $\mathrm{Co}_{x} \mathrm{Zn}_{(1-x)} \mathrm{Fe}_{2} \mathrm{O}_{4}$ series synthesised in CHFS using GSAS2; inset: detail of the (311) reflection throughout the same series

recovery values ( $>80$ for all samples and $>90 \%$ for all except CF4, CF5 and CF8). Nonconformant recovery values were only found in samples CFO4 and CF05, where an excess of cobalt compared to zinc and iron was found.

\section{Crystal structure}

XRD analyses showed that the synthesised compounds are, in general, monophasic and show a crystallographic pattern typical of spinels (Figure 2). The crystallographic identification of the different ferrites is based on the determination of the cell constant (CC) (deducible from the reflection positions in the diffraction pattern). Both the CHFS and the $\mathrm{HT} \mathrm{Ni} \mathrm{Zn}_{(1-x)} \mathrm{Fe}_{2} \mathrm{O}_{4}$ samples show bigger crystallites (Table 4) and higher phase

purity than $\mathrm{Co}_{x} \mathrm{Zn}_{(1-\mathrm{x})} \mathrm{Fe}_{2} \mathrm{O}_{4}$. In particular, HT-synthesised $\mathrm{CoFe}_{2} \mathrm{O}_{4}$ displays two reflections at $47.2^{\circ}$ and $48.2^{\circ}$ not relatable to the spinel crystal phase.

In order to determine if it was possible to insert the substituting metal in the crystal structure of the spinel, an analysis of how the CC changed as a function of the nominal composition was carried out. A linear behaviour is expected according to Vegard's law: 48

$\mathrm{CC}_{\mathrm{B}_{\mathrm{x}} \mathrm{A}_{(1-\mathrm{x})}}=(1-\mathrm{x}) \mathrm{CC}_{\mathrm{A}}+\mathrm{xCC}_{\mathrm{B}}$

And linearised as displayed in Figures 3 and 449-52

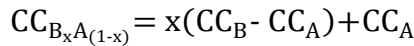

Where $\mathrm{CC}_{\mathrm{A}_{(1-x)} \mathrm{B}_{\mathrm{x}}}$ is the cell constant of the quaternary ferrite, $\mathrm{x}$ is the molar amount of the substituting metal and $\mathrm{CC}_{\mathrm{A}}$ and $\mathrm{CC}_{\mathrm{B}}$ are the cell constants of the pure $\mathrm{ZnFe}_{2} \mathrm{O}_{4}$ and $\mathrm{MFe}_{2} \mathrm{O}_{4}$ ternary ferrites respectively.

The CC vs. $x$ plots of the CHFS synthesised samples are displayed in Figure 3. The $\mathrm{CC}$ of the ternary $\mathrm{ZnFe}_{2} \mathrm{O}_{4}$ matches the one reported in the literature ${ }^{51}$ and a decreasing trend in the $\mathrm{CC}$ vs. substituting metal concentration values was observed for both $\mathrm{Co}_{x} \mathrm{Zn}_{(1-x)} \mathrm{Fe}_{2} \mathrm{O}_{4}$ and $\mathrm{Ni}_{x} \mathrm{Zn}_{(1-x)} \mathrm{Fe}_{2} \mathrm{O}_{4}$. This is consistent with equation (2), since $\mathrm{CC}_{\mathrm{A}}>\mathrm{CC}_{\mathrm{B}}$ both for the cobalt and nickel ternary ferrites. In particular, the $\mathrm{Ni}_{x} \mathrm{Zn}_{(1-x)} \mathrm{Fe}_{2} \mathrm{O}_{4}$ series shows a linear behaviour and a good adherence to literature data concerning ternary ferrites. A slight discrepancy between the experimental and literature reported ternary $\mathrm{NiFe}_{2} \mathrm{O}_{4} \mathrm{CC}$ could however be evidenced (experimental value - $8.327 \AA$ literature value $-8.342 \AA$ ). The $\mathrm{Co}_{x} \mathrm{Zn}_{(1-\mathrm{x})} \mathrm{Fe}_{2} \mathrm{O}_{4}$ series also displays the expected negative trend, showing however an ending-serie point that does not match the value reported for $\mathrm{CoFe}_{2} \mathrm{O}_{4}$ at $\mathrm{x}=1$ (full square in Figure 3 ). The first four 


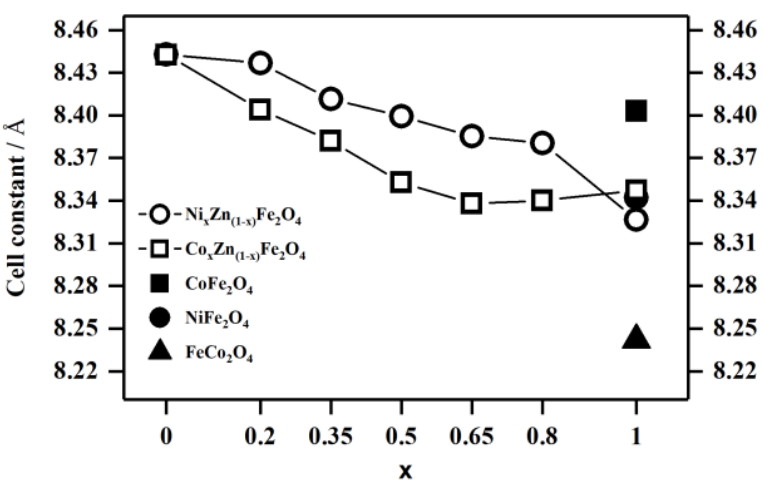

Fig. 3 Vegard plot of CHFS prepared samples. The black data points refer to the literature, whereas the white data points refer to the measured samples. ${ }^{49-52}$

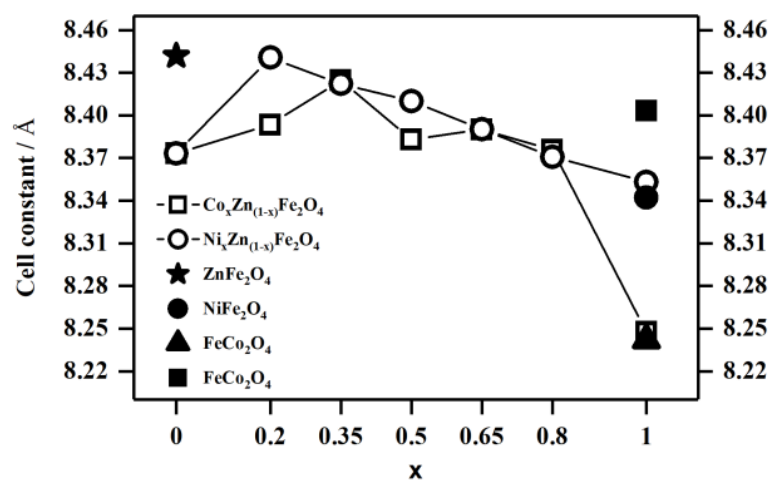

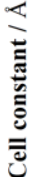

Tab. 5 Surface composition (atomic \%) of the samples.

\begin{tabular}{|c|c|c|c|c|c|c|c|c|}
\hline & & \multicolumn{3}{|c|}{ Retrieved atomic\% } & \multicolumn{2}{c|}{ Expected ratios } & \multicolumn{2}{c|}{ Retrieved ratios } \\
\hline Sample & Expected Formula & Co & Zn & Fe & Co/Zn & (Co+Zn)/Fe & Co/Zn & (Co+Zn)/Fe \\
\hline CF01 & $\mathrm{Co}_{0.2} \mathrm{Zn}_{0.8} \mathrm{Fe}_{2} \mathrm{O}_{4}$ & 7.4 & 24.7 & 67.9 & 0.25 & 0.50 & 0.30 & 0.47 \\
\hline CF02 & $\mathrm{Co}_{0.35} \mathrm{Zn}_{0.65} \mathrm{Fe}_{2} \mathrm{O}_{4}$ & 10.5 & 20.2 & 69.3 & 0.54 & 0.50 & 0.52 & 0.44 \\
\hline CF03 & $\mathrm{Co}_{0.5} \mathrm{Zn}_{0.5} \mathrm{Fe}_{2} \mathrm{O}_{4}$ & 17.0 & 13.7 & 69.2 & 1.00 & 0.50 & 1.24 & 0.44 \\
\hline CF04 & $\mathrm{Co}_{0.65} \mathrm{Zn}_{0.35} \mathrm{Fe}_{2} \mathrm{O}_{4}$ & 25.5 & 12.7 & 61.8 & 1.86 & 0.50 & 2.00 & 0.62 \\
\hline CF05 & $\mathrm{Co}_{0.8} \mathrm{Zn}_{0.2} \mathrm{Fe}_{2} \mathrm{O}_{4}$ & 29.5 & 6.5 & 64.1 & 4.00 & 0.50 & 4.57 & 0.56 \\
\hline CFCo & $\mathrm{CoFe}_{2} \mathrm{O}_{4}$ & 38.9 & $\mathrm{~N} / \mathrm{A}$ & 61.1 & $\mathrm{~N} / \mathrm{A}$ & 0.50 & $\mathrm{~N} / \mathrm{A}$ & 0.64 \\
\hline HT01 & $\mathrm{Co}_{0.22} \mathrm{Zn}_{0.8} \mathrm{Fe}_{2} \mathrm{O}_{4}$ & 9.7 & 40.4 & 49.9 & 0.25 & 0.50 & 0.24 & 1.01 \\
\hline HT02 & $\mathrm{Co}_{0.35} \mathrm{Zn}_{0.65} \mathrm{Fe}_{2} \mathrm{O}_{4}$ & 8.7 & 31.2 & 60.1 & 0.54 & 0.50 & 0.28 & 0.66 \\
\hline HT03 & $\mathrm{Co}_{0.5} \mathrm{Zn}_{0.5} \mathrm{Fe}_{2} \mathrm{O}_{4}$ & 15.0 & 22.9 & 62.1 & 1.00 & 0.50 & 0.65 & 0.61 \\
\hline HT04 & $\mathrm{Co}_{0.65} \mathrm{Zn}_{0.35} \mathrm{Fe}_{2} \mathrm{O}_{4}$ & 21.7 & 15.5 & 62.8 & 1.86 & 0.50 & 1.4 & 0.59 \\
\hline HT05 & $\mathrm{Co}_{0.8} \mathrm{Zn}_{0.2} \mathrm{Fe}_{2} \mathrm{O}_{4}$ & 28.5 & 9.5 & 62.0 & 4.00 & 0.50 & 3.0 & 0.61 \\
\hline HTCO & $\mathrm{CoFe}_{2} \mathrm{O}_{4}$ & 34.8 & N/A & 65.2 & N/A & 0.50 & N/A & 0.53 \\
\hline
\end{tabular}

datapoints $(0<x<0.5)$ seem to point to the $\mathrm{CC}$ value of $\mathrm{FeCO}_{2} \mathrm{O}_{4}$ and the last three points end up settling on a $\mathrm{CC}$ value similar to the ternary $\mathrm{NiFe}_{2} \mathrm{O}_{4}$.

The Vegard plots for the HT synthesised samples are displayed in Figure 4. The $\mathrm{CC}$ of $\mathrm{ZnFe}_{2} \mathrm{O}_{4}$ was calculated as $8.373 \AA$ compared to the $8.4419 \AA$ value reported in literature for pure $\mathrm{ZnFe}_{2} \mathrm{O}_{4} .{ }^{51} \mathrm{Ni}_{x} \mathrm{Zn}_{(1-x)} \mathrm{Fe}_{2} \mathrm{O}_{4}$ shows a near-perfect linear behaviour and the ternary $\mathrm{NiFe}_{2} \mathrm{O}_{4} \mathrm{CC}$ is in agreement with the one reported on literature, while $\mathrm{Co}_{x} \mathrm{Zn}_{(1-x)} \mathrm{Fe}_{2} \mathrm{O}_{4}$ series shows a less clear behaviour. The $\mathrm{CC}$ of the ternary $\mathrm{CoFe}_{2} \mathrm{O}_{4}$ matches the one of the iron cobaltite $\mathrm{FeCO}_{2} \mathrm{O}_{4}$.

From XRPD diffraction data analysis it emerged that both methods allowed predictable results in the $\mathrm{Ni}_{x} \mathrm{Zn}_{(1-x)} \mathrm{Fe}_{2} \mathrm{O}_{4}$ series, while a more complex situation was evident for the $\mathrm{Co}_{x} \mathrm{Zn}_{(1-x)} \mathrm{Fe}_{2} \mathrm{O}_{4}$ series. It is possible to hypothesise a formation of Coll', possibly related to the presence of the $\mathrm{Fe} / \mathrm{Fe}$ III equilibrium and the presence of $\mathrm{H}_{2} \mathrm{O}_{2}$ for the CHFS method. Indeed, the presence of metals in different oxidation states from the predicted ones in the crystal structure could result in cell variations that are not consistent with the Vegard plot.

\section{Surface analysis}

Due to XRD suggesting the presence of $\mathrm{FeCO}_{2} \mathrm{O}_{4}$ in the cobalt ferrite samples synthesised by CHFS (see below), XPS analyses
Fig. 4 Vegard plot of HT prepared samples. The black data points refer to the literature, whereas the white data points refer to the measured samples. ${ }^{49-52}$ were carried out on select samples both to investigate whether this also occurred on the surface and to gain further insight on surface composition and chemical environments.

As mentioned in the experimental section, a standard $\mathrm{Mg}$ source (as opposed to the more common Al $\mathrm{K}_{\alpha}$ source) was employed in order to avoid the overlap of Co2p and $\mathrm{FeL}_{3} \mathrm{M}_{45} \mathrm{M}_{45}$ peaks (both sets falling in the 775-795 eV interval with an $\mathrm{Al}$ source) and of the Fe2p and $\mathrm{CoL}_{2} \mathrm{M}_{23} \mathrm{M}_{45}$ (1P) peaks (all belonging to the $710-720 \mathrm{eV}$ region). ${ }^{41}$

Survey scans were initially collected from samples (Figure S1 in in Electronic Supplementary Information) to identify the chemical species present on the surface; based upon this data, high resolution multiplex scans were collected focussing on the regions of interest (i.e. C1s, O1s, Co2p, Fe2p and Zn2p). From these scans, quantitative information on the samples was gained (Table 5 reports a quantitative breakdown of the metals measured on the surface, whereas the results of a more comprehensive quantitative analysis are reported in Table S2 in Electronic Supplementary Information).

Concerning the samples synthesised through CHFS, the measured zinc content is slightly higher than the expected nominal ratio, whereas the $\mathrm{Co}+\mathrm{Zn} / \mathrm{Fe}$ ratio oscillates around the expected value of 0.5 . In samples prepared through batch hydrothermal synthesis though, both the zinc content and the 


\section{ARTICLE}

Tab. 6 Corrected binding energies (after surface charging measured for each element).

\begin{tabular}{|c|c|c|c|c|c|c|c|c|}
\hline Sample & Sample nature & $\begin{array}{c}\mathrm{Fe} 2 \mathrm{p}_{3 / 2} \\
(\mathrm{I})\end{array}$ & $\begin{array}{c}\mathrm{Fe} 2 \mathrm{p}_{3 / 2} \\
\text { (II) }\end{array}$ & $\begin{array}{c}\mathrm{Fe} 2 \mathrm{p}_{3 / 2} \\
\text { (III) }\end{array}$ & $\begin{array}{c}\mathrm{Co}_{2} \mathrm{p}_{3 / 2} \\
(\mathrm{I})\end{array}$ & $\begin{array}{c}\mathrm{Co}_{2} \mathrm{p}_{3 / 2} \\
\text { (II) }\end{array}$ & $\begin{array}{c}\mathrm{Co}_{2} \mathrm{p}_{3 / 2} \\
\text { (III) } \\
\end{array}$ & $\mathrm{Zn} 2 \mathrm{p}_{3 / 2}$ \\
\hline CF01 & $\mathrm{Co}_{0.2} \mathrm{Zn}_{0.8} \mathrm{Fe}_{2} \mathrm{O}_{4}$ & 710.4 & 712.7 & 718.6 & 779.6 & 780.7 & 787.6 & 1020.7 \\
\hline CF02 & $\mathrm{Co}_{0.35} \mathrm{Zn}_{0.65} \mathrm{Fe}_{2} \mathrm{O}_{4}$ & 710.5 & 712.6 & 718.6 & 780.0 & 782.1 & 786.6 & 1020.6 \\
\hline CF03 & $\mathrm{Co}_{0.5} \mathrm{Zn}_{0.5} \mathrm{Fe}_{2} \mathrm{O}_{4}$ & 710.4 & 712.4 & 718.4 & 780.3 & 781.6 & 786.9 & 1021.0 \\
\hline CF04 & $\mathrm{Co}_{0.65} \mathrm{Zn}_{0.35} \mathrm{Fe}_{2} \mathrm{O}_{4}$ & 710.3 & 712.5 & 717.9 & 780.1 & 781.7 & 786.7 & 1020.7 \\
\hline CF05 & $\mathrm{Co}_{0.8} \mathrm{Zn}_{0.2} \mathrm{Fe}_{2} \mathrm{O}_{4}$ & 710.2 & 712.5 & 718.2 & 779.9 & 781.8 & 787.0 & 1020.7 \\
\hline CFCo & $\mathrm{CoFe}_{2} \mathrm{O}_{4}$ & 709.9 & 712.1 & 718.4 & 780.0 & 782.1 & 786.5 & N/A \\
\hline HT01 & $\mathrm{Co}_{0.2} \mathrm{Zn}_{0.8} \mathrm{Fe}_{2} \mathrm{O}_{4}$ & 710.6 & 713.2 & 718.5 & 779.5 & 780.33 & & 1021.0 \\
\hline HT02 & $\mathrm{Co}_{0.35} \mathrm{Zn}_{0.65} \mathrm{Fe}_{2} \mathrm{O}_{4}$ & 710.6 & 713.2 & 718.6 & 780.2 & 780.6 & 786.8 & 1020.9 \\
\hline HT03 & $\mathrm{Co}_{0.5} \mathrm{Zn}_{0.5} \mathrm{Fe}_{2} \mathrm{O}_{4}$ & 710.6 & 713.4 & 718.6 & 780.2 & 781.2 & 787.4 & 1020.9 \\
\hline HT04 & $\mathrm{Co}_{0.65} \mathrm{Zn}_{0.35} \mathrm{Fe}_{2} \mathrm{O}_{4}$ & 710.3 & 713.2 & 718.5 & 779.9 & 781.6 & 786.4 & 1020.7 \\
\hline HT05 & $\mathrm{Co}_{0.8} \mathrm{Zn}_{0.2} \mathrm{Fe}_{2} \mathrm{O}_{4}$ & 710.3 & 713.0 & 718.6 & 779.9 & 7819 & 787.0 & 1020.6 \\
\hline HTCO & $\mathrm{CoFe}_{2} \mathrm{O}_{4}$ & 710.4 & 713.1 & 718.6 & 780.1 & & 786.5 & N/A \\
\hline
\end{tabular}

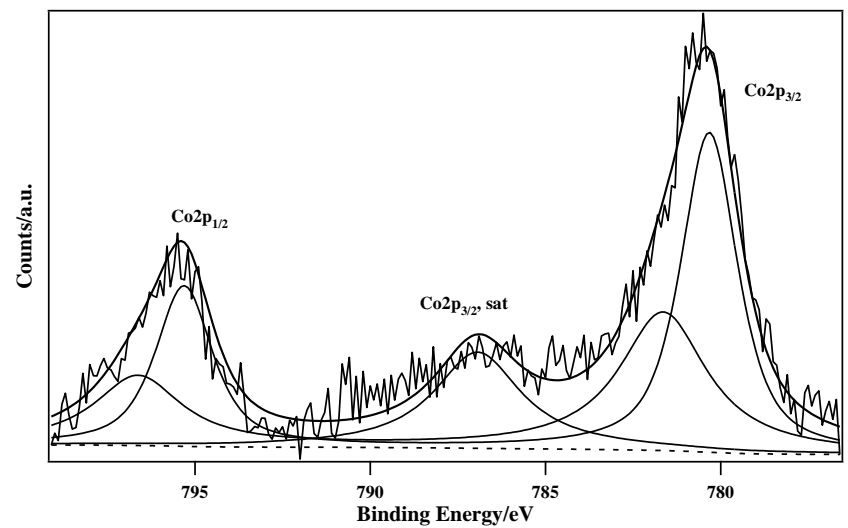

Fig. 5 Fitting of the Co2p region for sample CF03 (binding energies corrected for surface charging)

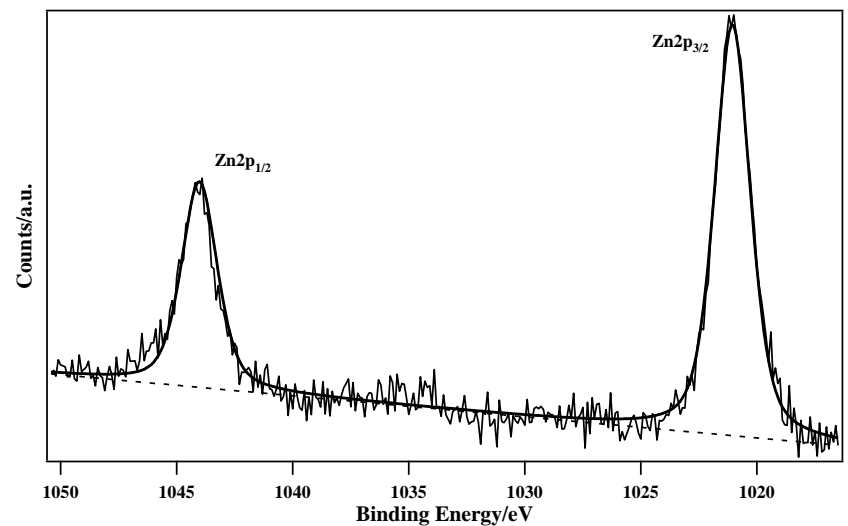

Fig. 7 Fitting of the $\mathrm{Zn} 2 \mathrm{p}$ region for sample $\mathrm{CFO}$ (binding energies corrected for surface charging)

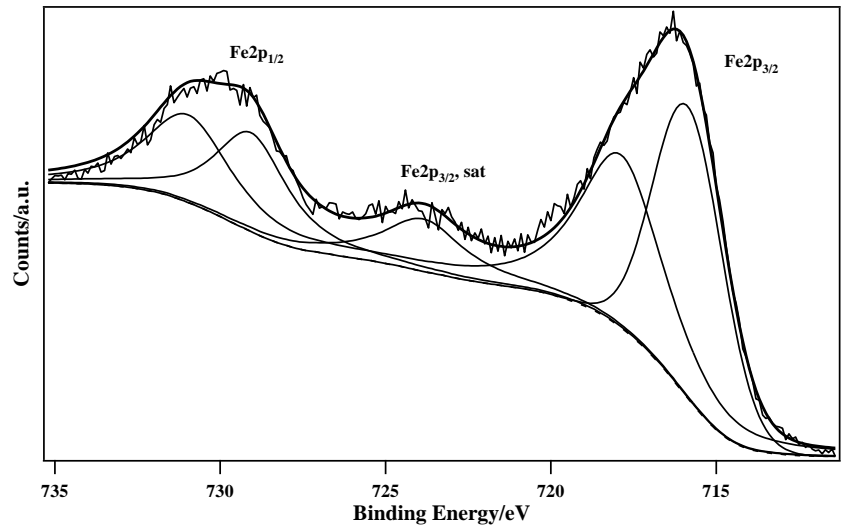

Fig. 6 Fitting of the Fe2p region for sample CF03 (binding energies corrected for surface charging)

$\mathrm{Co}+\mathrm{Zn} / \mathrm{Fe}$ ratios are higher than the expected stoichiometry would suggest. Though these results differ from the (more accurate) data obtained via ICP-MS (See Table 3), they can be ascribed to differences between surface and bulk composition, as well as to the lower precision in quantitative measurements afforded by XPS.

The Co2p and Fe2p regions for all samples (as well as the $\mathrm{Zn} 2 \mathrm{p}$ region for the zinc-containing samples) were further analysed through fitting to gain a more accurate understanding of the oxidation states of the metals involved (which would in turn yield important information on the compounds' composition as well as afford further insights on their structure and degrees of inversion). ${ }^{53}, 54$ Binding energy values (after correction for surface charging based upon the adventitious carbon C1s binding energy $-284.6 \mathrm{eV})^{41,42}$ for the fitted components are reported in Table 6 . As the $2 p_{1 / 2}$ is separated from the $2 p_{3 / 2}$ component by a fixed binding energy amount (13.1 eV for Fe2p, 
$15.0 \mathrm{eV}$ for Co $2 p$ and $23.0 \mathrm{eV}$ for $\mathrm{Zn} 2 \mathrm{p})^{41}$ the $2 \mathrm{p}_{1 / 2}$ components are not reported.

Observed values are in agreement with expectations for spinel ferrites ${ }^{38,55,56}$ and, as can be seen from Table 6, the influence of the increasing $\mathrm{Zn}$ content is not evident. Unfortunately, very few reports concerning XPS analysis of Zn-Co quaternary ferrites were found in literature to compare and reference these findings.

The Co2p region was fitted with three components, the first two ( $I$ and $I I$ in Table 6) attributed to Co"l in different chemical environments and the third to the $\operatorname{Co} 2 \mathrm{p}_{3 / 2}$ shake-up peak (i.e. the satellite peak - $\mathrm{Co} 2 p_{3 / 2}$, sat in Figure 5). Calculated binding energies for the fitted components are in agreement with literature reports for $\mathrm{Co}^{11}$ in quaternary $\mathrm{Zn}$-Co spinel ferrites. ${ }^{57}$ 59 The strong shake-up peak is also a very good indicator of the presence of Co", as it would be much weaker in the case of Co'l1.60

The fact that binding energies for all components are equal to or greater than $779.9 \mathrm{eV}$ suggests an absence of Co'll, as literature reports for $\mathrm{FeCO}_{2} \mathrm{O}_{4}$ ascribe to the $\mathrm{Co}$ "II $\mathrm{Co} 2 \mathrm{p}_{3 / 2}$ peak binding energies of $779 \mathrm{eV}, 57,61,62$ which would make them easily identifiable. The hypothesis of an absence of Co ${ }^{11 \prime}$ is further reinforced by the relative intensity of the satellite peak, which is typically less intense in the case of Co ${ }^{111} .59$

Like Co2p for, the Fe2p region was fitted with three components, the first two (I and II in Table 6) attributed to Fe ${ }^{\text {III }}$ in different chemical environments and the third to the Fe $2 \mathrm{p}_{3 / 2}$ shake-up peak (i.e. the satellite peak - Fe2 $\mathrm{p}_{3 / 2}$, sat in Figure 6). The measured binding energy values are similar to those found in bimetallic spinel ferrites. ${ }^{38}, 56,63$ Based upon the aforementioned shift in the Fe2 $\mathrm{p}_{3 / 2}$ (1) component binding energy with increasing $\mathrm{Zn}$ content, it can be hypothesised that this first component is relative to iron in close proximity with the $\mathrm{Zn}$-substituted sites and therefore subject to the influence of the compositional variation. No data has been however found in the literature supporting or confuting this hypothesis. The absence of Fe" is further reinforced by the position of the shake-up peak, as in the $\mathrm{Fe}^{\text {ll }}$ peak would have lower binding energy ( $6 \mathrm{eV}$ higher than the Fe $2 \mathrm{p}_{3 / 2}$ component, ${ }^{57,64}$ unlike in our samples where the energy difference is over $8 \mathrm{eV}$ ). This is also in agreement with previous data reported in literature for Zn-Co quaternary ferrites. ${ }^{59}$

In all quaternary ferrite samples, the $\mathrm{Zn} 2 \mathrm{p}$ peak was fitted with a single component (Figure 7); measured $\mathrm{Zn} 2 \mathrm{p}_{3 / 2}$ binding energy values are compatible with of the expected binding energy $(1020.6 \mathrm{eV})$ for a zinc spinel ferrite, ${ }^{38,58}$ this lack of significant shift in $\mathrm{Zn} 2 \mathrm{p}$ binding energy is also consistent with previous report for $\mathrm{Zn}$-Co quaternary ferrites. ${ }^{57-59}$

\section{Conclusions}

Two different hydrothermal synthesis routes (continuous flow hydrothermal synthesis and low-temperature batch hydrothermal synthesis) were used to prepare quaternary zinc ferrites $\mathrm{M}_{x} \mathrm{Zn}_{1-\mathrm{x}} \mathrm{Fe}_{2} \mathrm{O}_{4}$ ( $\mathrm{M}=\mathrm{Co}, \mathrm{Ni} ; \mathrm{x}=0.2,0.35,0.5,0.65,0.8$ ). Both methods afforded nanocrystalline powders. The former (CHFS) requires higher temperatures and a more complex setup, but is capable of continuous synthesis, and thus can afford a greater quantity of materials over time. By contrast, the latter method (HT) is far simpler and less time consuming to implement, but as a batch method, can only yield a limited mass of products in a given time span.

Compositional analyses via ICP-MS seem to indicate that the HT protocol was more successful in affording a good compositional control over the final products, as the $M / Z n$ ratio was different from the proposed stoichiometry in the two Co/Zn ferrites synthesised through CHFS with higher Co content $\left(\mathrm{Co}_{0.65} \mathrm{Zn}_{0.35} \mathrm{Fe}_{2} \mathrm{O}_{4}\right.$ and $\left.\mathrm{Co}_{0.8} \mathrm{Zn}_{0.2} \mathrm{Fe}_{2} \mathrm{O}_{4}\right)$.

\section{Conflicts of interest}

There are no conflicts to declare.

\section{Acknowledgements}

Financial support was provided by Royal Society of Chemistry within the International Exchanges Scheme - 2016/R1 for the joint UCL-CNR bilateral project "Sustainable hydrothermal synthesis routes for nanocrystalline ferrites" (2016-2018) as well as by the DFG via the GrK (Research training group) 2204 "Substitute Materials for sustainable Energy Technologies". S.G. gratefully acknowledges DFG and the Justus-Liebig Universität Gießen for the provision of a Mercator Fellowship (2016-2020). We would like to thank the Centre of Materials Research (LaMa) at Justus-Liebig Universität Gießen for the support of this project, in particular the department of Physical Chemistry is acknowledged for the access to the diffractometer used for the XRD measurements.

\section{References}

1. Y. Deng, J. Zhou, D. Wu, Y. Du, M. Zhang, D. Wang, H. Yu, S. Tang and Y. Du, Chem. Phys. Lett., 2010, 496, 301-305.

2. A. H. Latham and M. E. Williams, Acc. Chem. Res., 2008, 41, 411-420.

3. D. H. K. Reddy and Y.-S. Yun, Coord. Chem. Rev., 2016, 315, 90-111.

4. P. Lavela and J. L. Tirado, J. Power Sources, 2007, 172, 379387.

5. Y. Zhao, X. Li, B. Yan, D. Xiong, D. Li, S. Lawes and X. Sun, Adv. Energy Mater., 2016, 6, 1502175.

6. M. Florea, M. Alifanti, V. I. Parvulescu, D. MihailaTarabasanu, L. Diamandescu, M. Feder, C. Negrila and L. Frunza, Catal. Today, 2009, 141, 361-366.

7. A. V. Nakhate and G. D. Yadav, ChemistrySelect, 2017, 2, 2395-2405.

8. V. S. R. Kalluri, S. Melad, S. Aanchal and S. Gaddipati, Curr. Org. Chem., 2017, 21, 2573-2584.

9. Y. Zhang, H. Fang, Y. Zhang, M. Wen, D. Wu and Q. Wu, J. Colloid Interf. Sci., 2019, 535, 499-504.

10. G. B. Sergeev, in Nanochemistry, Elsevier Science, Amsterdam, 2006, DOI: https://doi.org/10.1016/B978044451956-6/50010-9, pp. 175-208. 
11. A. Sutka, G. Mezinskis, A. Lusis and D. Jakovlevs, Sensor Actuat. B-Chem., 2012, 171-172, 204-209.

12. A. Ramakrishna, N. Murali, S. J. Margarette, K. Samatha and V. Veeraiah, Physica B, 2018, 530, 251-257.

13 H. Shokrollahi and L. Avazpour, Particuology, 2016, 26, 32 39.

14. S. Ammar, N. Jouini, F. Fiévet, O. Stephan, C. Marhic, M. Richard, F. Villain, C. Cartier dit Moulin, S. Brice and P. Sainctavit, J. Non-Cryst. Solids, 2004, 345-346, 658-662.

15 L. Sichu, L. Limin, V. T. John, C. J. O'Connor and V. G. Harris, IEEE T. Magn., 2001, 37, 2350-2352.

16. R. Mohan, M. P. Ghosh and S. Mukherjee, J. Magn. Magn Mater., 2018, 458, 193-199.

17.

A. Yadav and D. Varshney, Superlattice. Microst., 2018, 113, 153-159.

18. C. Virlan, F. Tudorache and A. Pui, Int. J. Appl. Ceram. Tec. 2017, 14, 1174-1182.

$19 . \quad$ J.-S. Kim, J.-R. Ahn, C. W. Lee, Y. Murakami and D. Shindo J. Mater. Chem., 2001, 11, 3373-3376.

$20 . \quad$ K.-S. Lin, C.-L. Chiang, P.-J. Hsu, K. Bat-Erdene, C.-Y. Tang and C.-M. Wu, Catal. Today, 2018, 307, 260-271.

21. C. N. Chinnasamy, A. Narayanasamy, N. Ponpandian, K. Chattopadhyay, H. Guérault and J. M. Greneche, J. Phys. Condens. Matter, 2000, 12, 7795.

22. F. A. Cotton and G. Wilkinson, Advanced Inorganic Chemistry, $5^{\text {th }} E d$., John Wiley \& Sons, New York, 1988.

23. Y. Qu, H. Yang, N. Yang, Y. Fan, H. Zhu and G. Zou, Mater. Lett., 2006, 60, 3548-3552.

C. N. Chinnasamy, A. Narayanasamy, N. Ponpandian, K. Chattopadhyay, K. Shinoda, B. Jeyadevan, K. Tohji, K. Nakatsuka, T. Furubayashi and I. Nakatani, Phys. Rev. B: Condens. Matter Mater. Phys., 2001, 63, 184108/184101$184108 / 184106$.

25. C. E. Botez, K. Chattrakun, A. J. Metta-Magana, K. H. Pannell and J. A. Mattutes-Aquino, Phys. Lett. A, 2012, 376, 2730-2734.

26. R. Arulmurugan, B. Jeyadevan, G. Vaidyanathan and S Sendhilnathan, J. Magn. Magn. Mater., 2005, 288, 470477.

27. S. G. C. Fonseca, L. S. Neiva, M. A. R. Bonifácio, P. R. C. d. Santos, U. C. Silva and J. B. L. d. Oliveira, Mater. Res., 2018, 21.

28. M. A. Gabal, A. A. Al-Juaid, S. M. Al-Rashed, M. A. Hussein and F. Al-Marzouki, J. Magn. Magn. Mater., 2017, 426, 670-679.

29. T. R. Tatarchuk, M. Bououdina, N. D. Paliychuk, I. P. Yaremiy and V. V. Moklyak, J. Alloy Compd., 2017, 694, 777 791.

30. B. Rajesh Babu and T. Tatarchuk, Mater. Chem. Phys., 2018 207, 534-541.

31. M. M. Ismail and N. A. Jaber, Surf. Rev. Lett., 2017, 25 , 1850076.

32.

N. Thomas, P. V. Jithin, V. D. Sudheesh and V. Sebastian, Ceram. Int., 2017, 43, 7305-7310.

33. M. Junaid, M. A. Khan, F. Iqbal, G. Murtaza, M. N. Akhtar, M. Ahmad, I. Shakir and M. F. Warsi, J. Magn. Magn. Mater., 2016, 419, 338-344.

34. S. A. Morrison, C. L. Cahill, E. E. Carpenter, S. Calvin, R. Swaminathan, M. E. McHenry and V. G. Harris, J. Appl. Phys., 2004, 95, 6392-6395.

35. S. Chandrasekar, J. Chandrasekaran and E. R. Kumar, J. Adv. Phys., 2015, 4, 199-203.

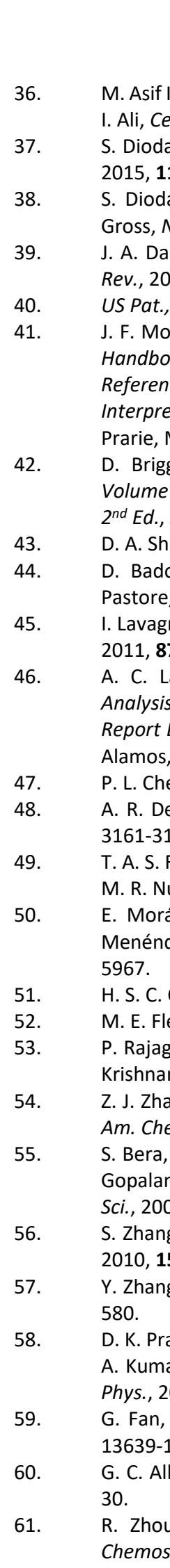

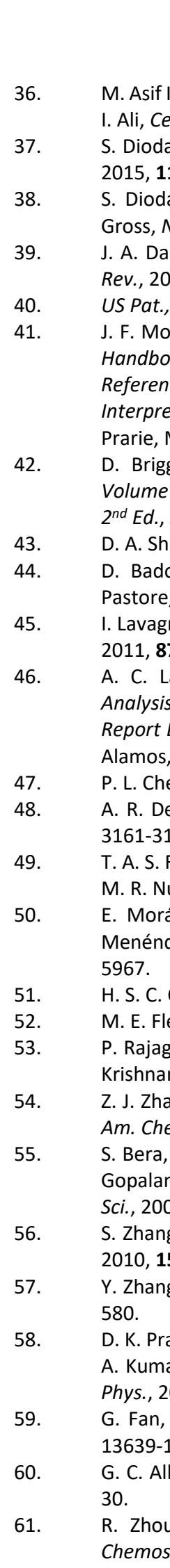

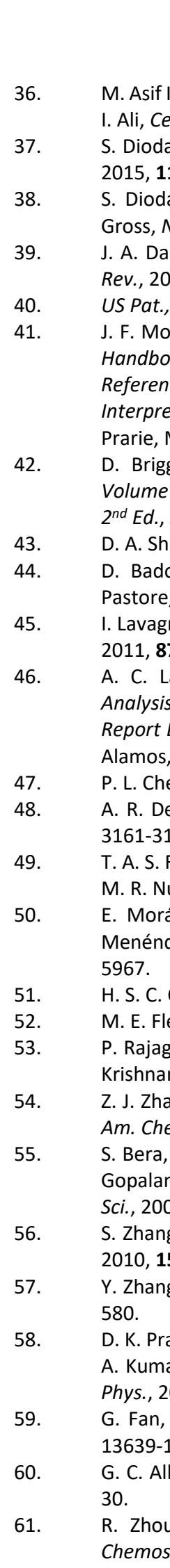

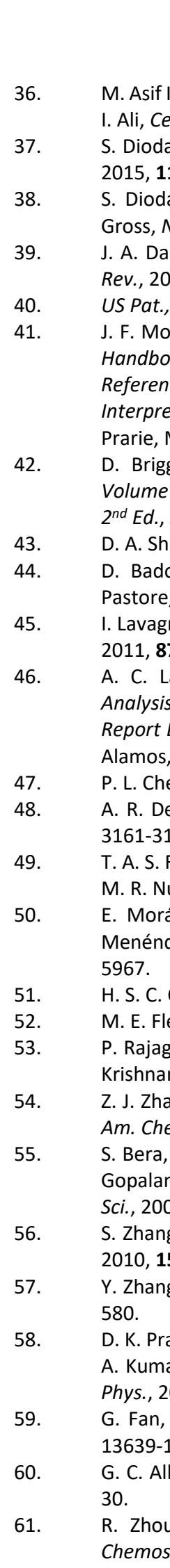

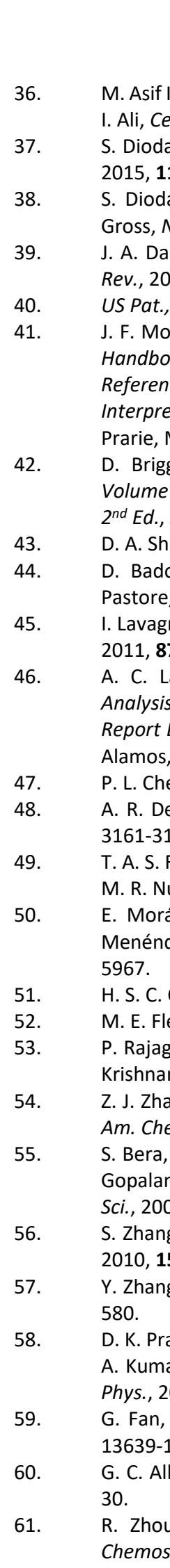

Ceft

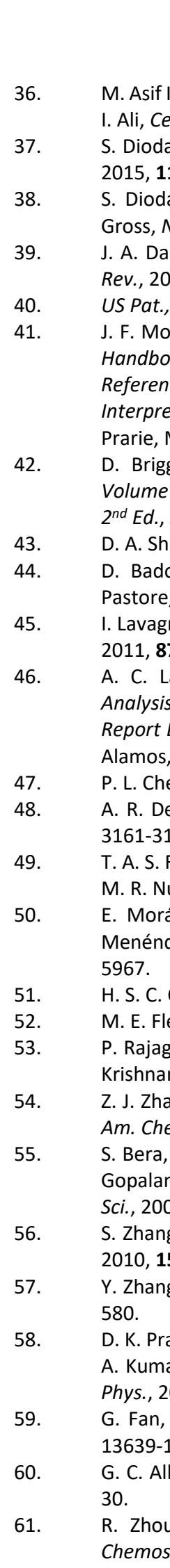

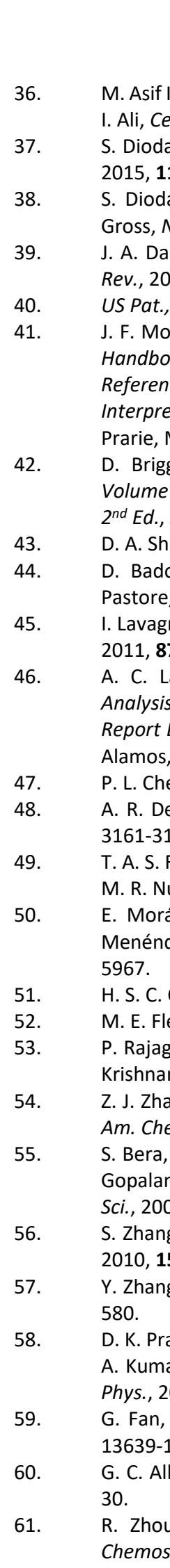

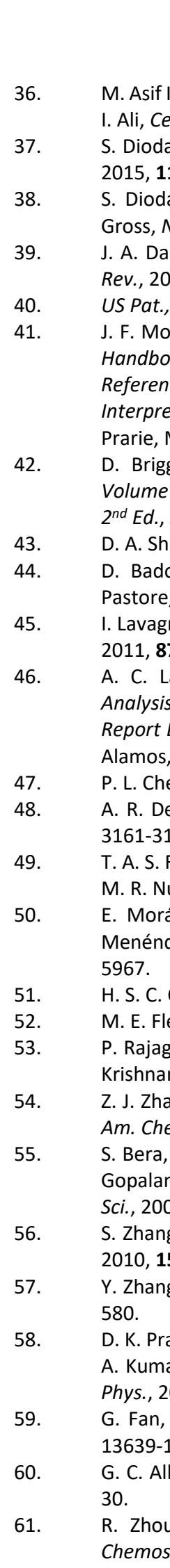

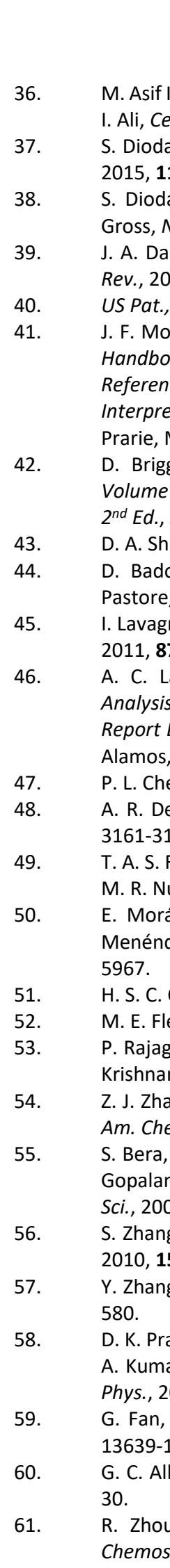

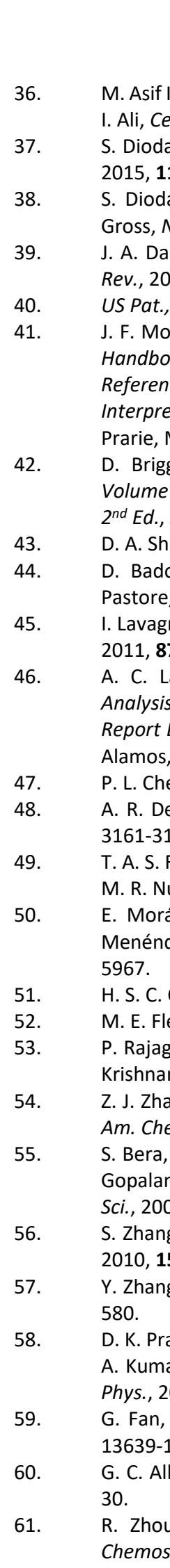

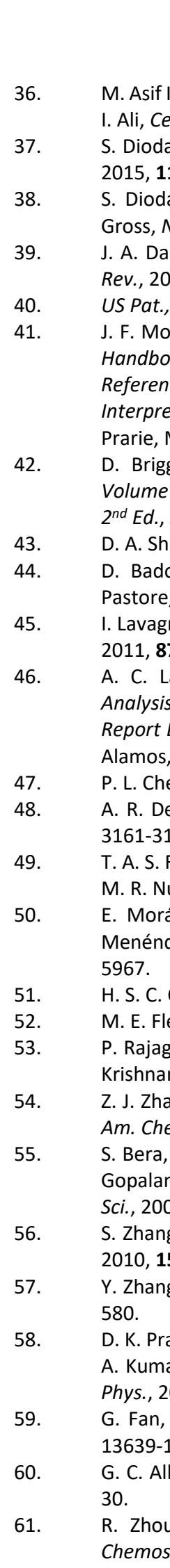

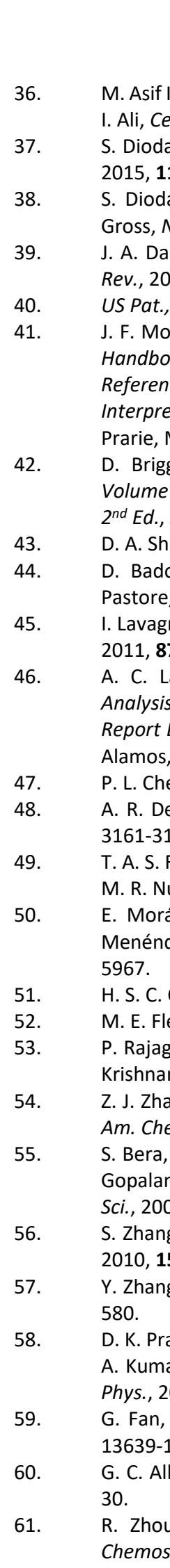

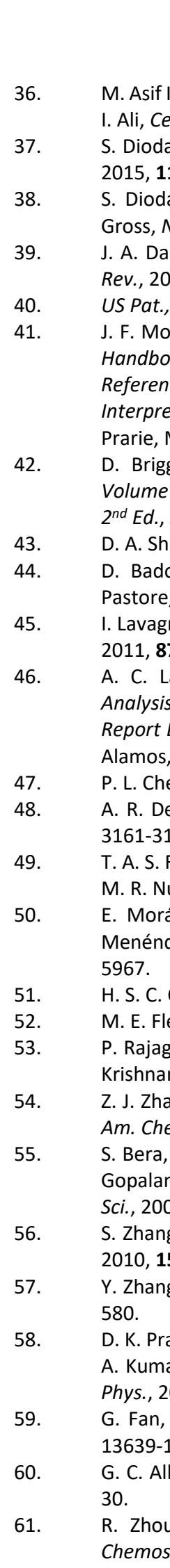

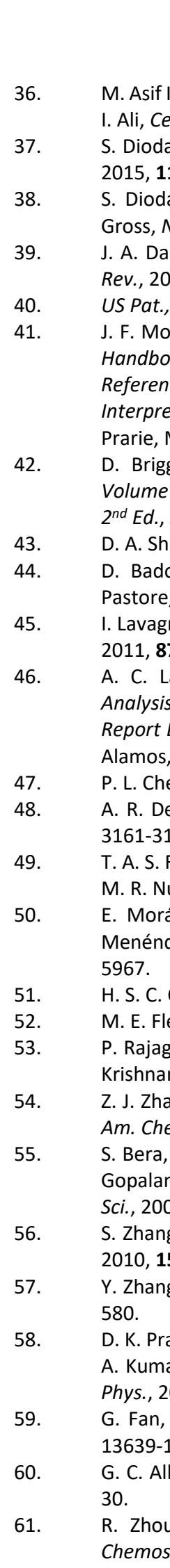

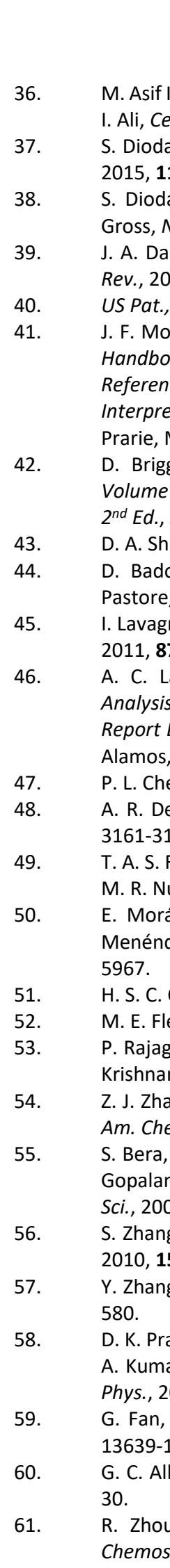

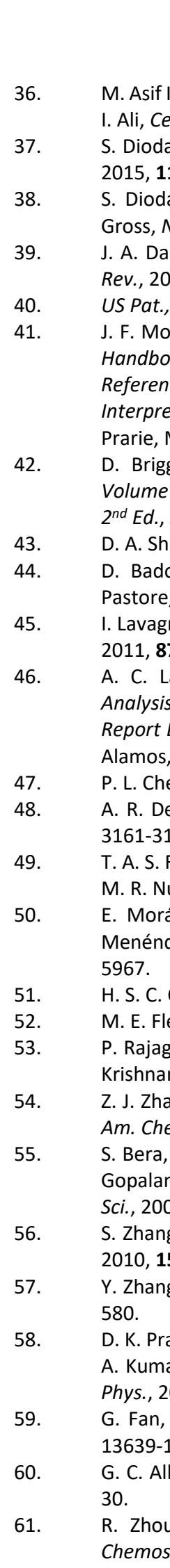

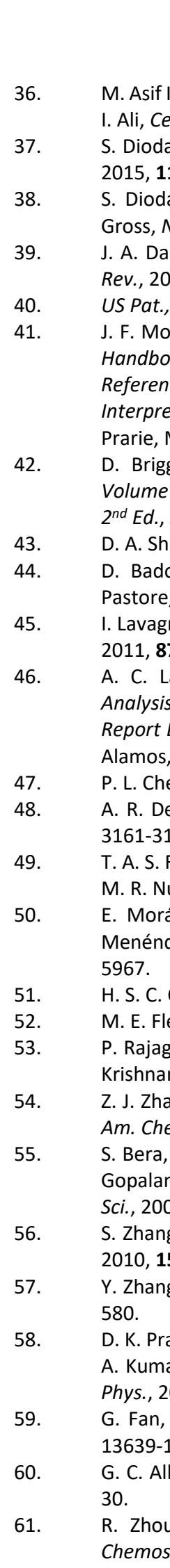

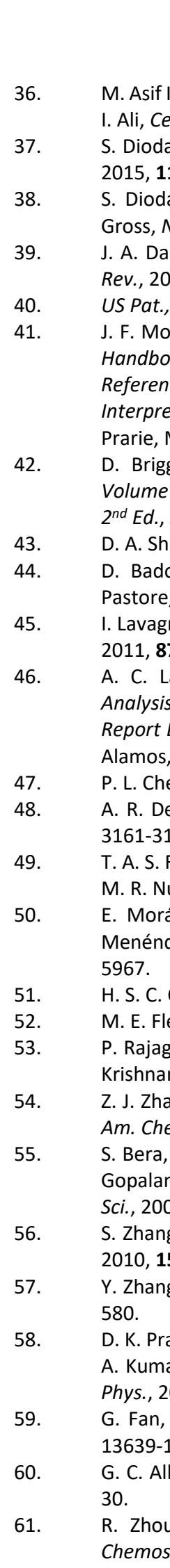

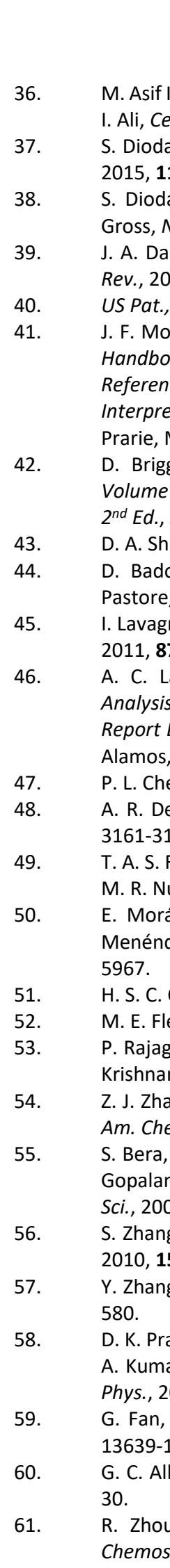

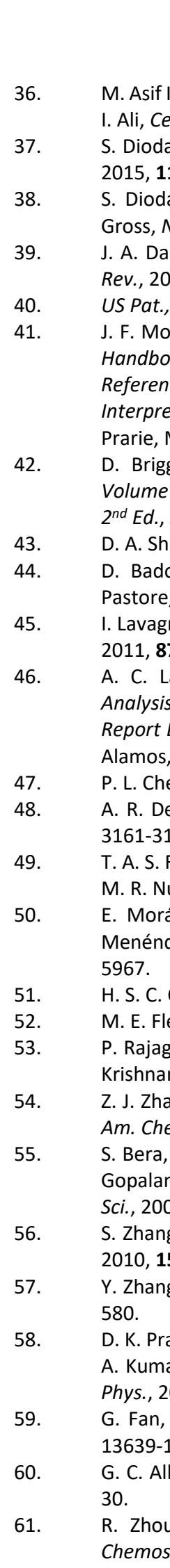

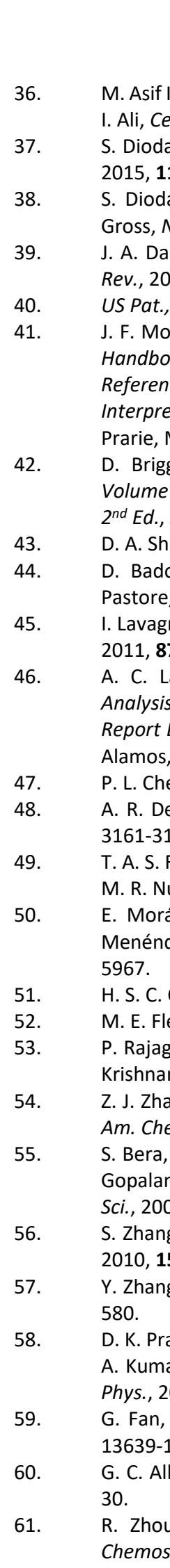

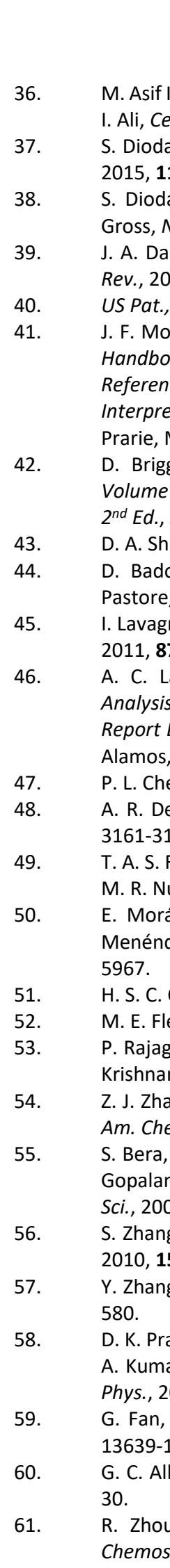

(58.

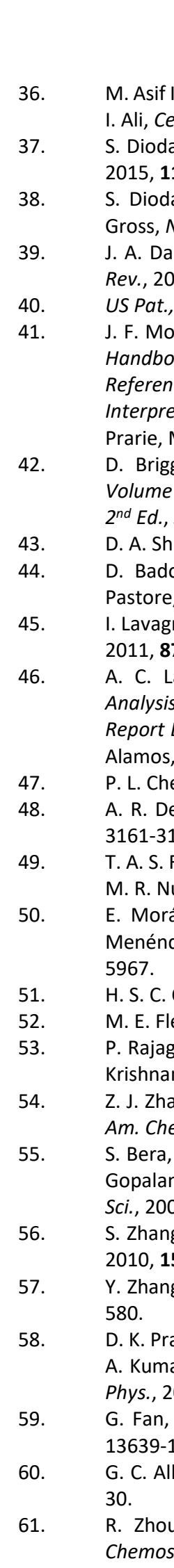

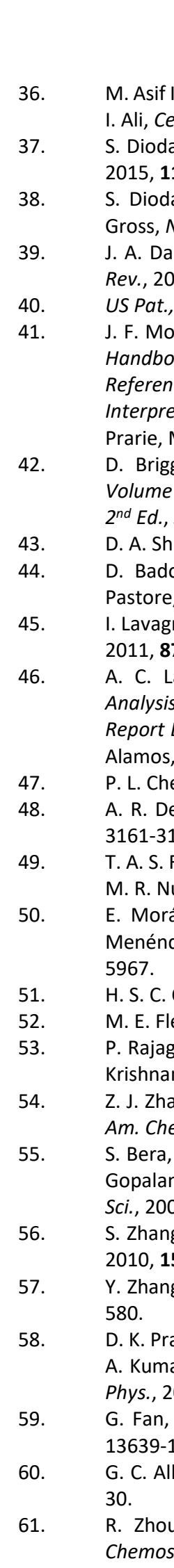

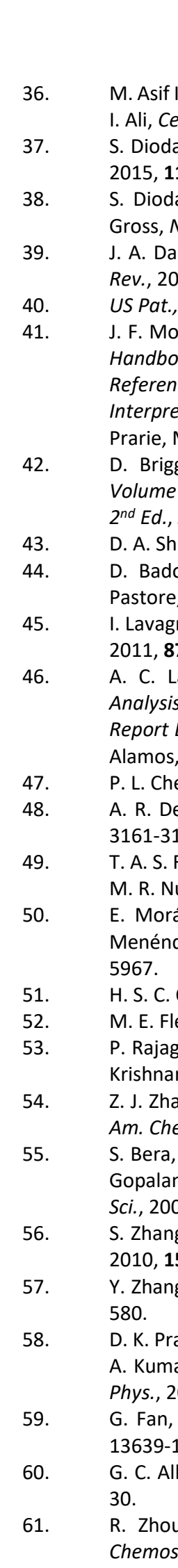

62.

63. Y. Sharma, N. Sharma, G. V. Subba Rao and B. V. R. Chowdari, Solid State Ionics, 2008, 179, 587-597.

H. Lee, J. C. Jung, H. Kim, Y.-M. Chung, T. J. Kim, S. J. Lee, S.H. Oh, Y. S. Kim and I. K. Song, Catal. Lett., 2008, 124, 364368. 
64. V. K. Mittal, S. Bera, R. Nithya, M. P. Srinivasan, S. Velmurugan and S. V. Narasimhan, J. Nucl. Mater., 2004, 335, 302-310. 